\title{
Drift algal subsidies to sea urchins in low-productivity habitats
}

\author{
Jennifer R. Kelly ${ }^{1,2, *}$, Kira A. Krumhansl ${ }^{1}$, Robert E. Scheibling ${ }^{1}$ \\ ${ }^{1}$ Department of Biology, Dalhousie University, Halifax, Nova Scotia B3H 4J1, Canada \\ ${ }^{2}$ Present address: Department of Zoology, University of British Columbia, Vancouver, British Columbia V6T 1Z4, Canada
}

\begin{abstract}
Highly productive kelp beds off the coast of Nova Scotia, Canada, export a large quantity of detrital material to adjacent low-productivity habitats. We used a combination of dietary tracers (fatty acids, stable isotopes, and gut contents) and gonad index to evaluate the importance and spatial extent of this energy subsidy to green sea urchins Strongylocentrotus droebachiensis offshore from kelp beds along $240 \mathrm{~m}$ transects perpendicular to the shore at 4 sites. Gut contents and $\delta^{13} \mathrm{C}$ values indicated the presence of kelp in the diets of sea urchins collected up to $240 \mathrm{~m}$ offshore from kelp beds. We observed a corresponding decrease in gonad index with distance from the kelp at all sites but one, where patches of live kelp offshore from the main kelp bed provided an additional food source. Sea urchins that fed on a large pool of detrital kelp at another site had $\sim 15 \%$ larger gonads than sea urchins at other locations. $\delta^{15} \mathrm{~N}$ values were more enriched for sea urchins at 160 and $240 \mathrm{~m}$ from the kelp bed, suggesting that these sea urchins consume more animal matter, which was also evident in their gut contents. Our findings suggest that drift kelp represents an important energy source for sea urchins in subtidal habitats on the scale of tens to hundreds of meters offshore from kelp beds and that this resource is increasingly patchy in space and time with distance from the kelp bed.
\end{abstract}

KEY WORDS: Stable isotopes · Fatty acids $\cdot$ Trophic subsidy $\cdot$ Detritus $\cdot$ Kelp beds $\cdot$ Sea urchins • Strongylocentrotus droebachiensis

\section{INTRODUCTION}

Trophic linkages between discrete habitats are a common feature of marine ecosystems (Kirkman \& Kendrick 1997, Polis et al. 1997, Heck et al. 2008). Transfer of macrophyte detritus from a habitat with high primary productivity, such as kelp forests or seagrass beds, to an adjacent one with lower primary productivity, such as mudflats, rocky reefs or the deep sea, can be an important determinant of community structure and secondary production in the subsidized habitat (Polis et al. 1997, Vetter 1998, Heck et al. 2008, Vanderklift \& Wernberg 2008). Detrital transport across the seafloor is wave- and current-driven and therefore affected by regionalscale oceanographic processes, seasonal storms, and bottom topography (Bustamante \& Branch 1996, Vetter 1998, Vetter \& Dayton 1999, Rodríguez 2003, Vanderklift \& Wernberg 2008). Consequently, the availability of this resource to consumers in linked seafloor habitats can be patchy in space and time (Vetter 1998, Rodríguez 2003, Britton-Simmons et al. 2009).

Kelp forests are among the most productive habitats in the world, but the majority of kelp biomass is transported to other habitats as detritus rather than being directly grazed (Cebrian 1999, Krumhansl \& Scheibling 2011). Drift from subtidal kelp beds is a major food source for consumers in intertidal and offshore habitats. In the Benguela Current system off the coast of South Africa, drift kelp increases secondary production in the intertidal zone by providing food for limpets (Bustamante et al. 1995, Bustamante 
\& Branch 1996). On the Chilean coast, intertidal sea urchins feed preferentially on drift kelp where it is available, and sea urchins with access to this resource develop larger gonads than those feeding on intertidal algae (Rodríguez 2003). Kelps growing on offshore rocky reefs off the coast of western Australia provide a subsidy to adjacent seagrass beds (Wernberg et al. 2006) and other reefs kilometers away (Vanderklift \& Wernberg 2008). On the Pacific coast of Washington, USA, sea urchins in deeper water offshore from kelp beds capture drift algae and develop gonads as large as those in shallow subtidal habitats (Britton-Simmons et al. 2009). However, the availability of drift algae and sea urchin gonad size both decrease with distance from shore in northern California (Rogers-Bennett et al. 1995).

Along the Atlantic coast of Nova Scotia, Canada, coralline algal-dominated barrens are found offshore from kelp beds in the rocky subtidal. Although primary productivity is much lower in these barrens than in adjacent kelp beds (Chapman 1981), they often support dense populations of the green sea urchin Strongylocentrotus droebachiensis (80 to 100 urchins $\mathrm{m}^{-2}$ at 18 to $24 \mathrm{~m}$ depth; Himmelman 1986, Brady \& Scheibling 2005). These sea urchins generally have smaller gonads and slower somatic growth than sea urchins actively feeding on the kelp bed (Himmelman 1986, Brady \& Scheibling 2006). Drift from nearby kelp beds may provide a substantial energy subsidy to these sea urchin populations, as detrital kelp production can reach $1.7 \mathrm{~kg}$ dry weight $\mathrm{m}^{-2} \mathrm{yr}^{-1}$ (Krumhansl \& Scheibling 2011). Sea urchins in barrens opportunistically consume drift algae when it is available (Himmelman \& Steele 1971, Johnson \& Mann 1982, Himmelman 1986, Meidel \& Scheibling 1998), but the abundance and spatial extent of this detrital material in offshore barrens, and its importance in sea urchin diets, are unknown.

Diets of marine invertebrates have been identified by analyzing gut contents and by using chemical tracers such as stable isotopes (SI) and fatty acids (FA). Gut contents provide information on an organism's diet in the relatively short term but can overestimate the contribution of the most recently consumed food items and those that are digested more slowly (Foale \& Day 1992). Chemical tracers may provide longer-term and less biased dietary information (Iverson et al. 2004), but their interpretation may be complicated if animals consume mixed diets or modify chemical signatures of their food (Peterson 1999, Kelly et al. 2008, 2009). Carbon isotopic ratios can be used to identify the sources of primary production contributing to higher trophic levels, while nitrogen isotopic ratios increase with each trophic transfer such that the relative trophic position of various consumers can be identified (Peterson \& Fry 1987). Characteristic FAs for various classes of primary producers are transferred to higher trophic levels conservatively and can be used to identify food sources of consumers (Graeve et al. 1994, Dalsgaard et al. 2003). Some invertebrates are capable of substantial biosynthesis or selective retention of dietary FAs, which dilute dietary signals, although consumers of different diets may still differ in their overall FA composition (Kelly et al. 2008, 2009). The results of chemical tracer analyses are most robust when corroborated by other lines of evidence (Peterson 1999) and studies using a combination of analytical methods to study diet are common (Graeve et al. 2001, Kharlamenko et al. 2001, Rodríguez 2003, Crawley et al. 2009, Guest et al. 2010, Hanson et al. 2010).

We measured gonad production, gut contents, stable carbon and nitrogen isotopic signatures, and FA composition of green sea urchins in rocky subtidal habitats offshore from kelp beds to address the following questions: (1) What is the spatial extent of drift kelp subsidy to sea urchins in deeper-water habitats offshore from kelp beds? (2) How does the relative contribution of drift kelp and autochthonous production in the diets of sea urchins change at increasing distance offshore from kelp beds? (3) How do the gut contents, SI and FA of sea urchins differ on the scale of tens to hundreds of meters?

\section{MATERIALS AND METHODS}

\section{Study sites}

Field collections took place in April 2009 at 4 sites on the Atlantic coast of Nova Scotia (Fig. 1). Sampling was conducted in April to coincide with peak gonad development in Strongylocentrotus droebachiensis in this region (Meidel \& Scheibling 1998). Sites were selected to represent different bathymetric profiles in areas where green sea urchins were known to be abundant (Brady \& Scheibling 2005, Lauzon-Guay \& Scheibling 2007): Gill Cove $\left(44^{\circ} 29.8^{\prime} \mathrm{N}, 63^{\circ} 31.7^{\prime} \mathrm{W}\right)$ and Duncan's Cove $\left(44^{\circ} 29.2^{\prime} \mathrm{N}, 63^{\circ} 31.2^{\prime} \mathrm{W}\right)$ both had a steep slope offshore from the edge of the kelp bed, while Black Rock $\left(44^{\circ} 27.1^{\prime} \mathrm{N}, 63^{\circ} 31.8^{\prime} \mathrm{W}\right)$ and Splitnose Point $\left(44^{\circ} 28.6^{\prime} \mathrm{N}, 63^{\circ} 32.7^{\prime} \mathrm{W}\right)$ had more gradual slopes (Fig. 2a). Depth was measured every $1.6 \mathrm{~m}$ along each transect by using side imaging sonar (Humminbird 1198c). Substratum type and macroalgae were recorded along each transect with an un- 


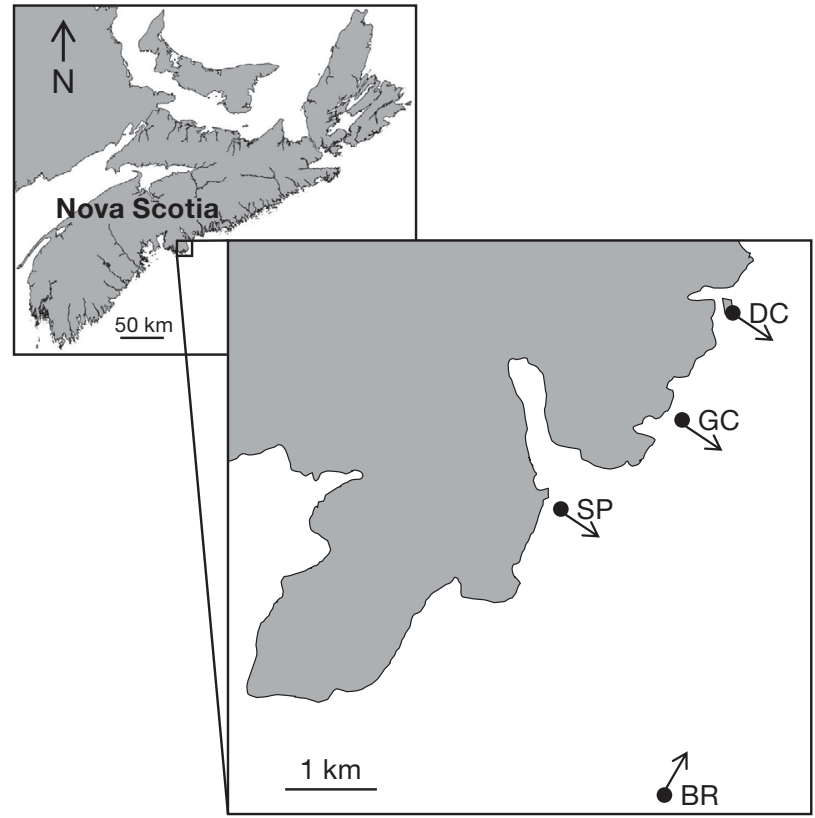

Fig. 1. Study site locations off the Atlantic coast of Nova Scotia, Canada. Inset shows starting point $(\bullet)$ and direction $(\rightarrow)$ of $240 \mathrm{~m}$ transect at each study site. BR: Black Rock; DC: Duncan's Cove; GC: Gill Cove; SP: Splitnose Point. Arrow size is not to scale

a)
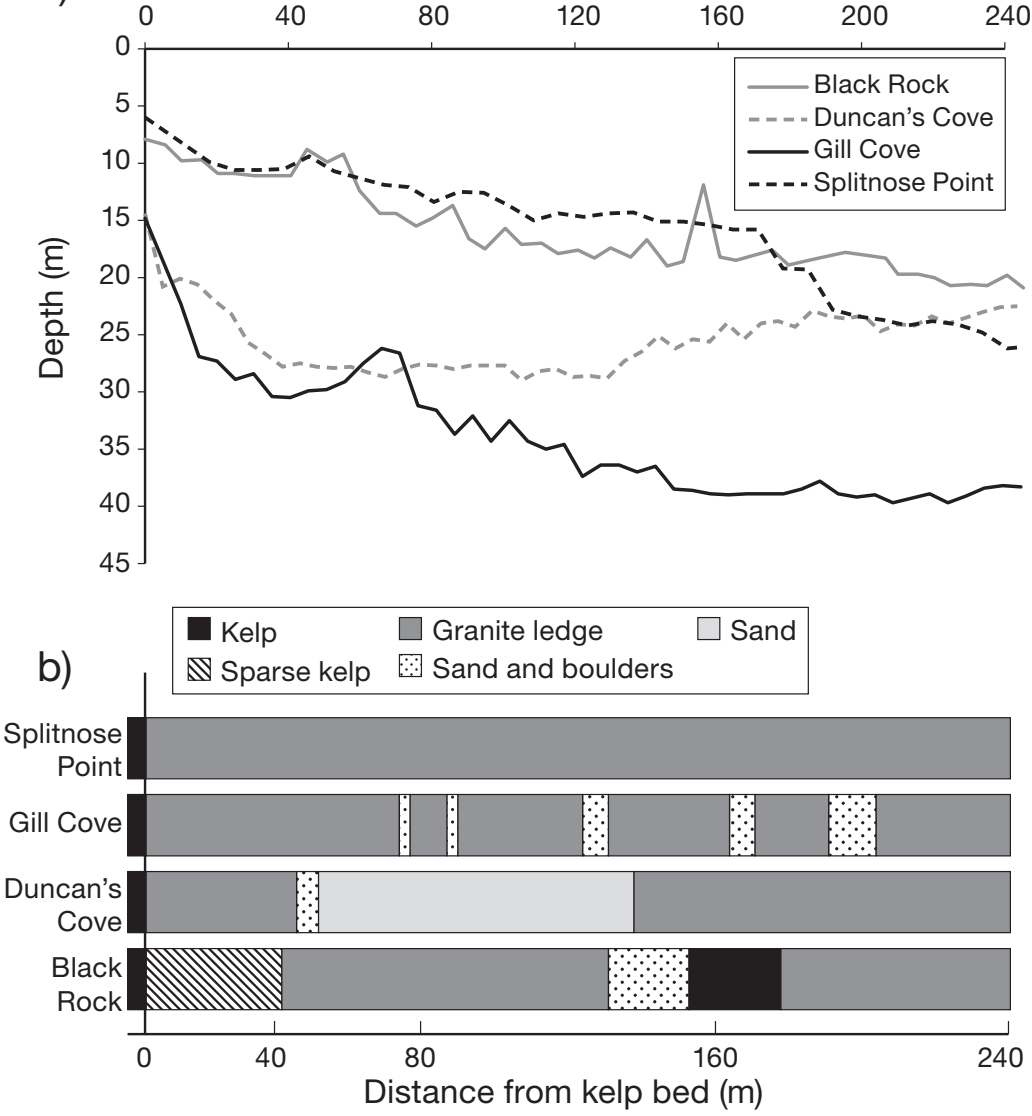

derwater video camera (Shark Marine SV-16HR Mini Colour Camera mounted on a JW Fisher DD1 deep dive wing) towed at a height of 1 to $2 \mathrm{~m}$ off the bottom and a speed of 0.25 to $0.5 \mathrm{~m} \mathrm{~s}^{-1}$. At all sites, Saccharina latissima (formerly S. longicruris; McDevit \& Saunders 2010), and Laminaria digitata were the dominant canopy-forming kelps in the shallow subtidal zone. Other macroalgae, mainly Desmarestia spp., Agarum cribrosum, Alaria esculenta, Bonnemaisonia hamifera and Palmaria palmata, were present in low abundances at all sites. Below $8 \mathrm{~m}$ depth, attached fleshy macroalgae were rare and crustose coralline algae, mainly Lithothamnion glaciale and Phymatolithon lenormandii, were dominant on the rocky substratum until this graded to sand. The substratum at Black Rock consisted mainly of granite ledges and boulders along the length of the transect, except for a $25 \mathrm{~m}$ long patch of sand and boulders beginning $127 \mathrm{~m}$ from the kelp bed (Fig. 2b). Sparsely distributed kelp was present to $40 \mathrm{~m}$ beyond the edge of the dense kelp bed, and a dense stand of kelp was present on a shoal (12 to $19 \mathrm{~m}$ depth) between 150 and $175 \mathrm{~m}$ from the main kelp bed. Duncan's Cove was characterized by granite ledges and boulders that transitioned to mixed sand and cobbles around $47 \mathrm{~m}$ from the kelp bed, and then back to granite ledges and boulders at $142 \mathrm{~m}$ from the kelp bed. A large deposit of kelp detritus was present $40 \mathrm{~m}$ from the kelp bed. At Gill Cove, granite ledges and boulders were interspersed with small patches ( 3 to $14 \mathrm{~m}$ in length) of sand and boulders beginning around $70 \mathrm{~m}$ from the kelp bed. The substratum at Splitnose Point consisted of granite ledges and boulders along the entire transect.

\section{Sample collection}

At each site, green sea urchins were collected by means of SCUBA along transects extending offshore from the edge of the kelp bed (perpendicular to shore). Sea urchins were haphazardly collected at the edge of the kelp bed ( $0 \mathrm{~m}$ distance) and at

Fig 2. Transects along which green sea urchins Strongylocentrotus droebachiensis were collected at 4 study sites. Sea urchins were collected at the edge of the kelp bed $(0 \mathrm{~m})$ and at 40, 80, 160 and $240 \mathrm{~m}$ along the transect. (a) Depth profiles and (b) substratum type are shown for each transect 
$40,80,160$ and $240 \mathrm{~m}$ linear distance along the sea surface along each transect ( $\mathrm{n} \geq 9$ sea urchins at each location). The 2 deepest locations (160 and $240 \mathrm{~m}$ from the kelp bed at Gill Cove) were beyond diving depth, so sea urchins were collected by using lobster traps baited with fish. Bait was placed in mesh bags inside a perforated plastic container to prevent sea urchins from consuming it, and traps were retrieved after $24 \mathrm{~h}$.

Dominant macroalgae were collected from the kelp bed and adjacent barrens for $\delta^{13} \mathrm{C}$ and $\delta^{15} \mathrm{~N}$ SI characterization. Sea urchins and algae were transferred to the laboratory; algae were immediately prepared for SI analysis (see 'Stable isotope analysis' below), and sea urchins were held in aquaria with flowing seawater before processing. Sea urchins were processed in random order over a $10 \mathrm{~d}$ period.

\section{Sea urchin metrics}

The test diameter of each sea urchin was measured with digital calipers. Wet weights of whole sea urchins (drained on paper towel for $30 \mathrm{~s}$ ) and excised gonads were measured with a digital balance $(0.01 \mathrm{~g}$ accuracy). The gonad index (GI) was calculated as (gonad wet weight/total wet weight) $\times 100$. Sex was determined from a gonad smear observed under a compound microscope.

\section{Gut contents analysis}

After excision of the gonads, gut contents were removed from the digestive tract and stored in $70 \%$ ethanol for later analysis. Gut content particles were spread on a $5 \times 5 \mathrm{~cm}$ grid with 121 intersection points and examined under a dissecting microscope. Items observed at intersection points were recorded. These items included kelp, Desmarestia spp., other brown algae, green algae, red filamentous and fleshy algae, coralline algae, zoaria of the kelpencrusting bryozoan Membranipora membranacea, parts of other invertebrates (mainly brittle stars, polychaete worms, and sea urchins), and unidentified material. The abundance of each item was calculated relative to the total number of intersection points where a food item was present. Because dissections were spread over $10 \mathrm{~d}$ after collection and sea urchins egested some of their gut contents during this interval, we measured the relative abundance of various food items but not the total volume of gut contents.

\section{Stable isotope analysis}

For SI analysis, algal material was cleaned of epiphytes, rinsed in distilled water, dried at $60^{\circ} \mathrm{C}$ for $48 \mathrm{~h}$ to a constant weight, and ground to a fine, homogeneous powder with a mortar and pestle. For sea urchins, the muscles of the Aristotle's lantern were extracted from 5 sea urchins for each distance at each site, rinsed in distilled water, acidified in $1 \mathrm{~N} \mathrm{HCl}$, and ground (Rodríguez 2003). $\delta^{13} \mathrm{C}$ and $\delta^{15} \mathrm{~N}$ were measured separately for acidified samples. Algal and sea urchin samples were sent to the University of California Davis Stable Isotope Facility or Stable Isotopes in Nature Lab at the University of New Brunswick for analysis.

The isotopic value of each sample is reported in $\delta$ notation as: $\delta X(\%)=\left(R_{\text {sample }} / R_{\text {standard }}-1\right) \times 1000$, where $\delta X=\delta^{13} \mathrm{C}$ or $\delta^{15} \mathrm{~N}$, where $R$ is the ratio of heavy to light isotope $,{ }^{13} \mathrm{C}:{ }^{12} \mathrm{C}$ and ${ }^{15} \mathrm{~N}:{ }^{14} \mathrm{~N}$, respectively. Air and Vienna Pee Dee Belmenite were used as standards for nitrogen and carbon, respectively.

\section{Lipid extraction and fatty acid analysis}

For lipid extraction, $1.5 \mathrm{~g}$ of gonad from each sea urchin was manually homogenized with $20 \mathrm{ml}$ chloroform and $10 \mathrm{ml}$ methanol containing $0.01 \%$ butylated hydroxytoluene (BHT) as an antioxidant. The same solvent ratio was maintained for sea urchins with $<1.5 \mathrm{~g}$ total gonad. Lipid extraction protocols were modified from Folch et al. (1957), as described in Kelly et al. (2008). The samples in solvent (sea urchin gonad or algae) were filtered (Fisher P8 filter paper) to remove residual tissue before adding $7 \mathrm{ml}$ of $5 \%$ $\mathrm{NaCl}$. Samples were shaken and then centrifuged for $20 \mathrm{~min}$. The lipid-containing lower phase was filtered through $\mathrm{Na}_{2} \mathrm{SO}_{4}$ and evaporated to dryness under nitrogen gas at 25 to $30^{\circ} \mathrm{C}$ in a pre-weighed boiling tube. The boiling tube was re-weighed to calculate the amount of crude lipid for each sample.

To prepare lipids for FA analysis, crude lipid was dissolved in $1.5 \mathrm{ml}$ methylene chloride with $0.01 \%$ BHT and subjected to acidic transesterification $\left(\mathrm{H}_{2} \mathrm{SO}_{4}\right.$ in methanol) to produce FA methyl esters (FAMEs), as described in Budge et al. (2006). FAMEs were purified to remove proteins and pigments by using thin layer chromatography (TLC). FAMEs were dissolved in hexane and spotted onto silica-gel TLC plates (Sigma) and developed in a TLC chamber with 90:10:1 petroleum ether:ethyl ether:acetic acid for approximately $45 \mathrm{~min}$. Plates were sprayed with 2,7 dichlorofluorescein and viewed under UV light to 
mark the FAME-containing band. The FAME-containing band was then scraped from the silica plate and transferred to a funnel packed with silanetreated glass wool. Chloroform containing $0.01 \%$ BHT was used to dissolve FAMEs into a pre-weighed tube. The sample was evaporated to dryness under nitrogen at 25 to $30^{\circ} \mathrm{C}$ and hexane was added to a final concentration of $50 \mathrm{mg} \mathrm{ml}^{-1}$. Samples were stored at $-20^{\circ} \mathrm{C}$ prior to analysis.

Duplicate samples of FAMEs were analyzed and FAs identified using temperature-programmed gas chromatography (Iverson et al. 1997, 2004, Budge et al. 2006).

\section{Statistical analysis}

Sea urchin test diameter, GI, gut contents (percent kelp and percent coralline algae) and SI $\left(\delta^{13} \mathrm{C}\right.$ and $\delta^{15} \mathrm{~N}$ ) values were compared with a 2-way ANOVA that used site and distance from the kelp bed as fixed factors. For each site significant 2-way interactions were further examined with a 1-way ANOVA that used distance from the kelp bed as a fixed factor. Gonad lipid content (percent wet weight) was also compared among distances at each site with 1-way ANOVA because of missing values due to gonad samples that were too small for lipid analysis. Post hoc comparisons were made following significant 1-way ANOVA results $(\alpha=0.01)$ with Tukey's honestly significant difference test (HSD) where Levene's test indicated equal variances, and Games-Howell tests where variances were unequal. Test diameter and SI data were untransformed, GI data were log transformed and gonad lipid and gut contents data were arcsine transformed. Transformations generally produced normal and homoscedastic data (Shapiro-Wilk and Levene's tests, $p>0.05$ ). ANOVA and pairwise comparisons were conducted with SYSTAT 12 software.

FA with an overall mean contribution of $>0.1 \%$ were included in statistical analyses, and FA composition was standardized to $100 \%$ for all samples prior to analysis. Overall FA composition was compared by using permutational multivariate ANOVA (PERMANOVA, Anderson 2001) on Bray-Curtis distances of untransformed data and site and distance from the kelp bed were used as fixed factors. Homogeneity of multivariate dispersions of FA data was tested by using permutational analysis of multivariate dispersions (PERMDISP, Anderson 2004). For each site the significant interaction was further examined with 1-way PERMANOVA with distance as a fixed factor, and multidimensional scaling (MDS) plots for each site. Multivariate analyses were conducted by using PRIMER 6 software with the PERMANOVA+ package (Clarke \& Gorley 2006).

\section{RESULTS}

There was a general trend of decreasing test diameter and GI with distance from the kelp bed (Fig. 3a,b), although this effect varied across sites, as indicated by a significant interaction between site and distance for both variables (Table 1). Mean GI in sea urchins ranged from 22.4 at $40 \mathrm{~m}$ from the kelp bed at Duncan's Cove to 0.67 at $240 \mathrm{~m}$ from the kelp bed at Splitnose Point (Fig. 3b). GI decreased significantly with distance from the kelp bed at all sites except Black Rock (Table 2). At Black Rock, GI did not differ with distance from the kelp bed except at $80 \mathrm{~m}$, where it was significantly lower (Table 2).

There was a significant interactive effect of site and distance on both kelp and coralline algae in the sea urchin gut contents (Table 1, Fig. 3c,d). The proportion of kelp in the gut contents generally decreased with distance from the kelp bed, except at Black Rock, where sea urchins $160 \mathrm{~m}$ from the kelp bed had significantly higher kelp content than did sea urchins at other distances (Table 2, Fig. 3). Sea urchins $40 \mathrm{~m}$ from the kelp bed at both Black Rock and Duncan's Cove also had high kelp content (Fig. 3c). The proportion of kelp in the gut contents did not differ significantly with distance from the kelp bed at Splitnose Point (Table 2). The proportion of coralline algae in the gut contents generally increased with distance from the kelp bed, except at Black Rock (Table 2, Fig. 3d). Gut contents of sea urchins from $240 \mathrm{~m}$ from the kelp bed were characterized by a high proportion of animal material (Table 3).

Mean $\delta^{13} \mathrm{C}$ of the 2 dominant kelp species ranged from -17.71 to $-14.96 \%$ for Laminaria digitata and from -18.66 to $-17.11 \%$ for Saccharina latissima (Table 4). Most other algal species were more depleted than kelps, with Desmarestia spp. being the most depleted $\left(-33.00 \%\right.$ ). Mean $\delta^{15} \mathrm{~N}$ ranged from 4.59 to $6.68 \%$ for L. digitata, and from 4.03 to $7.29 \%$ for $S$. latissima (Table 4).

$\delta^{13} \mathrm{C}$ for sea urchins generally was more depleted with distance from the kelp bed, except at Black Rock (Fig. 4), and there was a significant interactive effect of site and distance (Table 1). The greatest range in mean $\delta^{13} \mathrm{C}$ was recorded at Splitnose Point, from -16.23 at the edge of the kelp bed to -18.4 at $240 \mathrm{~m}$ from the bed (Fig. 4). Average $\delta^{13} \mathrm{C}$ values for sea urchins fell within $1 \mathrm{SE}$ of kelp $\delta^{13} \mathrm{C}$ values, except for 

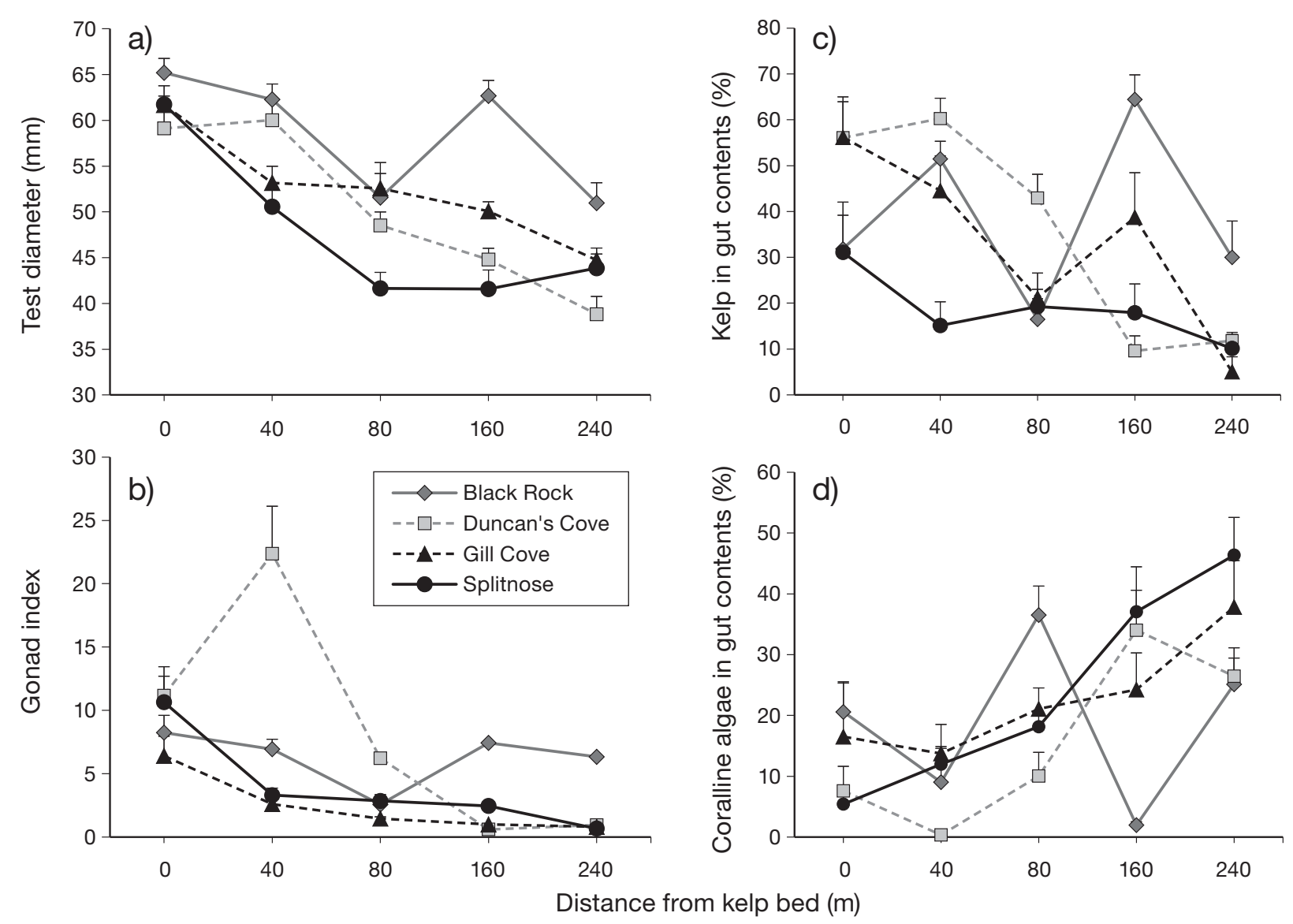

Fig. 3. Strongylocentrotus droebachiensis. (a) Test diameter, (b) gonad index, (c) percent kelp in gut contents, and (d) percent coralline algae in gut contents of green sea urchins along transects offshore from kelp beds

sea urchins $240 \mathrm{~m}$ from the kelp bed at Duncan's Cove and Splitnose Point, which were more depleted, and sea urchins at the edge of the kelp bed at Splitnose Point, which were more enriched than kelp (Fig. 4).

$\delta^{15} \mathrm{~N}$ for sea urchins generally was more enriched with distance from the kelp bed, except at Black Rock (Fig. 4), and there was a significant interactive effect of site and distance (Table 1). At Duncan's Cove, Gill Cove and Splitnose Point, $\delta^{15} \mathrm{~N}$ was significantly more enriched at sites distant from the kelp bed (Table 2). Mean $\delta^{15} \mathrm{~N}$ ranged from 6.69 at $40 \mathrm{~m}$ from the kelp bed at Black Rock to 9.98 at $240 \mathrm{~m}$ from the kelp bed at Gill Cove (Fig. 4). Average $\delta^{15} \mathrm{~N}$ for sea urchins was 1.6 to $4.9 \%$ more enriched than that of kelp.

Lipid content of sea urchin gonads ranged from 1.5 to $9.7 \%$ by weight (pooled mean $\pm \mathrm{SD}=4.5 \pm 1.5 \%$ ) and did not differ among sites or distances from the kelp bed (Table 2). There was a significant interactive effect of site and distance from the kelp bed on overall FA composition of sea urchin gonads (Table 1). FA composition differed among distances from the kelp bed at Black Rock, Duncan's Cove and
Gill Cove but not at Splitnose Point (Table 2). Multivariate dispersion was homogeneous across sites and distances (PERMDISP, $p>0.5$ ). Samples did not cluster by distance from the kelp bed and no spatial pattern was evident in MDS of FA composition. FAs identified as markers for brown algae (18:1n-9, $18: 4 n-3,20: 4 n-6)$ and diatoms $(16: 1 n-7,20: 5 n-3)$ in other studies (Dalsgaard et al. 2003, Kelly et al. 2008, 2009) were present in sea urchins at all sites and distances, but there was no detectable spatial pattern in their relative abundance (Appendix 1).

\section{DISCUSSION}

Various lines of evidence suggest that drift kelp is an important nutritional subsidy for sea urchins distant from kelp beds and contributes more to secondary production by sea urchins than encrusting corallines or other macroalgae, such as Desmarestia viridis, which is chemically defended from grazers (Molis et al. 2009). This is consistent with observations 
Table 1. Strongylocentrotus droebachiensis. Results of 2-way tests with site and distance from the kelp bed as fixed factors. Test diameter, gonad index, percent kelp and coralline algae in gut contents, and stable isotope values were compared using 2-way ANOVA. Fatty acid composition was compared using 2-way permutational multivariate ANOVA (PERMANOVA)

\begin{tabular}{|c|c|c|c|c|c|}
\hline Variable & Source & df & MS & $F$ & $\mathrm{p}$ \\
\hline Test diameter & $\begin{array}{l}\text { Site } \\
\text { Distance } \\
\text { Site } \times \text { Distance } \\
\text { Error }\end{array}$ & $\begin{array}{r}3 \\
4 \\
12 \\
221\end{array}$ & $\begin{array}{r}1113.82 \\
2093.28 \\
194.99 \\
41.83\end{array}$ & $\begin{array}{r}26.63 \\
50.04 \\
4.66\end{array}$ & $\begin{array}{l}<0.001 \\
<0.001 \\
<0.001\end{array}$ \\
\hline Gonad index & $\begin{array}{l}\text { Site } \\
\text { Distance } \\
\text { Site } \times \text { Distance } \\
\text { Error }\end{array}$ & $\begin{array}{r}3 \\
4 \\
12 \\
218\end{array}$ & $\begin{array}{r}13.73 \\
29.78 \\
7.91 \\
0.51\end{array}$ & $\begin{array}{l}26.93 \\
58.41 \\
15.51\end{array}$ & $\begin{array}{l}<0.001 \\
<0.001 \\
<0.001\end{array}$ \\
\hline $\begin{array}{l}\text { Kelp in } \\
\text { gut contents (\%) }\end{array}$ & $\begin{array}{l}\text { Site } \\
\text { Distance } \\
\text { Site } \times \text { Distance } \\
\text { Error }\end{array}$ & $\begin{array}{r}3 \\
4 \\
12 \\
199\end{array}$ & $\begin{array}{l}0.60 \\
0.94 \\
0.42 \\
0.06\end{array}$ & $\begin{array}{r}10.50 \\
16.44 \\
7.28\end{array}$ & $\begin{array}{l}<0.001 \\
<0.001 \\
<0.001\end{array}$ \\
\hline $\begin{array}{l}\text { Coralline algae } \\
\text { in gut contents }(\%)\end{array}$ & $\begin{array}{l}\text { Site } \\
\text { Distance } \\
\text { Site } \times \text { Distance } \\
\text { Error }\end{array}$ & $\begin{array}{r}3 \\
4 \\
12 \\
199\end{array}$ & $\begin{array}{l}0.22 \\
0.74 \\
0.25 \\
0.04\end{array}$ & $\begin{array}{r}4.97 \\
16.73 \\
5.78\end{array}$ & $\begin{array}{r}0.002 \\
<0.001 \\
<0.001\end{array}$ \\
\hline Muscle $\delta^{13} \mathrm{C}$ & $\begin{array}{l}\text { Site } \\
\text { Distance } \\
\text { Site } \times \text { Distance } \\
\text { Error }\end{array}$ & $\begin{array}{r}3 \\
4 \\
12 \\
93\end{array}$ & $\begin{array}{l}1.07 \\
4.14 \\
1.61 \\
0.45\end{array}$ & $\begin{array}{l}2.39 \\
9.23 \\
3.59\end{array}$ & $\begin{array}{r}0.074 \\
<0.001 \\
<0.001\end{array}$ \\
\hline Muscle $\delta^{15} \mathrm{~N}$ & $\begin{array}{l}\text { Site } \\
\text { Distance } \\
\text { Site } \times \text { Distance } \\
\text { Error }\end{array}$ & $\begin{array}{r}3 \\
4 \\
12 \\
93\end{array}$ & $\begin{array}{r}13.03 \\
9.94 \\
1.14 \\
0.25\end{array}$ & $\begin{array}{r}51.24 \\
39.09 \\
4.49\end{array}$ & $\begin{array}{l}<0.001 \\
<0.001 \\
<0.001\end{array}$ \\
\hline FA composition & $\begin{array}{l}\text { Site } \\
\text { Distance } \\
\text { Site } \times \text { Distance } \\
\text { Error }\end{array}$ & $\begin{array}{r}3 \\
4 \\
8 \\
150\end{array}$ & $\begin{array}{l}149.74 \\
454.57 \\
200.70 \\
106.82\end{array}$ & $\begin{array}{l}1.40 \\
4.26 \\
1.88\end{array}$ & $\begin{array}{l}0.150 \\
0.001 \\
0.002\end{array}$ \\
\hline
\end{tabular}

that these barrens macroalgae are of low nutritional value to sea urchins, compared with kelp (Meidel \& Scheibling 1999, Scheibling \& Hatcher 2007). However, the percentage of kelp in the gut contents of sea urchins decreased with distance from the kelp bed, suggesting that the quantity of this trophic subsidy declines with distance from the kelp bed. Carbon isotopic signatures of sea urchins generally were more depleted with distance from the kelp bed, except at Black Rock, where there was no spatial pattern in $\delta^{13} \mathrm{C}$ signatures. At Splitnose Point and Duncan's Cove, $\delta^{13} \mathrm{C}$ signatures of sea urchins $240 \mathrm{~m}$ from the kelp bed (-18.4\%) approached values for coralline algae found in the literature ( -22 to $-26 \%$, Hanson et al. 2010), suggesting that these sea urchins consumed more coralline algae than have those closer to the kelp bed. This depleted $\delta^{13} \mathrm{C}$ value for sea urchins also could reflect the consumption of $D$. aculeata or D. viridis $(-33 \%$, Table 4$)$, although these species were not abundant in kelp beds or barrens at our sites, and D. viridis is avoided by sea urchins because of its chemical defense (Lyons \& Scheibling 2008). The offshore stand of kelp at Black Rock probably obscured any effects of distance from the near-shore kelp bed on the dietary contribution of kelp and other algal food sources at this site.

$\delta^{15} \mathrm{~N}$ signatures were more enriched with increasing distance from the kelp bed, which may indicate an increase in the trophic position of sea urchins. The median value for $\delta^{15} \mathrm{~N}$ enrichment between kelp (5 to $6 \%$ ) and sea urchins (median $=8 \%$ across all sites and distances, Fig. 4) was comparable with the average trophic enrichment value $(2.75 \%$ ) calculated by Caut et al. (2009) for invertebrates. The relatively low values for $\delta^{15} \mathrm{~N}$ enrichment nearer to the kelp bed $(0$ to $80 \mathrm{~m}$ ) at all sites except Black Rock indicates a mainly herbivorous diet, whereas $\delta^{15} \mathrm{~N}$ enrichment of 3 to $4 \%$ (relative to $6 \%$ for Saccharina latissima) at 160 and $240 \mathrm{~m}$ from the kelp beds at Duncan's Cove, Gill Cove, and Splitnose Point suggests an increase in trophic position. This is consistent with the observation that 10 to $50 \%$ of the gut contents of sea urchins at $240 \mathrm{~m}$ from kelp beds was composed of animal material at these 3 sites compared with 3 to $7 \%$ for sea urchins at the kelp bed. However, the contribution of animal material to the diets of sea urchins is probably overestimated relative to that of non-coralline algal material because of the longer residence time of hard food items in the gut (Boolootian \& Lasker 1964, Foale \& Day 1992, Sauchyn \& Scheibling 2009). A shift in the SI signature of degrading drift kelp also may contribute to the spatial pattern of $\delta^{15} \mathrm{~N}$ enrichment we observed with increasing distance from the kelp bed. $\delta^{15} \mathrm{~N}$ isotopic signatures of Saccharina latissima shifted by an average of $\sim 1.0 \%$ over a 16 wk degradation period (Krumhansl \& Scheibling in press). However, the magnitude of $\delta^{15} \mathrm{~N}$ enrichment due to degradation alone is insufficient to explain the more enriched $\delta^{15} \mathrm{~N}$ values of sea urchins at 160 and $240 \mathrm{~m}$ from the kelp bed, indicating that animal material probably contributed substantially to their diet. 
Table 2. Strongylocentrotus droebachiensis. Results of 1way tests for each site with distance from the kelp bed $(0,40$, 80,160 and $240 \mathrm{~m}$ ) as a fixed factor. Test diameter, gonad lipid content, gonad index, percent kelp and coralline algae in gut contents, and stable isotope values were compared by using 1-way ANOVA. Post hoc comparisons are presented with levels in ascending order of magnitude; locations with common underlining are not significantly different from each other $(\alpha=0.01)$. Tukey's honestly significant difference (HSD) test was used where Levene's test indicated equal variances, and Games-Howell tests were used in cases of unequal variance (indicated by ${ }^{*}$ ). All data were normal except gonad index at Splitnose Point (Shapiro-Wilk test, $\mathrm{p}=$ 0.045). Fatty acid (FA) composition was tested using 1-way permutational multivariate ANOVA (PERMANOVA; $F$ is pseudo- $F$ statistic) with pairwise comparisons

\begin{tabular}{|c|c|c|c|c|}
\hline $\begin{array}{l}\text { Variable and } \\
\text { site }\end{array}$ & $\mathrm{df}$ & $F$ & $\mathrm{p}$ & $\begin{array}{l}\text { Pairwise } \\
\text { comparisons }\end{array}$ \\
\hline \multicolumn{5}{|l|}{ Test diameter } \\
\hline Black Rock & 4,48 & 12.07 & $<0.001$ & 014016080240 \\
\hline Duncan's Cove & 4,67 & 37.54 & $<0.001$ & 04080160240 \\
\hline Gill Cove & 4,45 & 9.19 & $<0.001$ & $\overline{040} \overline{80160240}$ \\
\hline Splitnose Point & 4,61 & 16.89 & $<0.001$ & $0 \underline{4080160240}{ }^{*}$ \\
\hline \multicolumn{5}{|c|}{ Gonad lipid content } \\
\hline Black Rock & 2,29 & 2.69 & 0.091 & \\
\hline Duncan's Cove & 4,49 & 0.47 & 0.757 & \\
\hline Gill Cove & 3,30 & 0.19 & 0.900 & \\
\hline Splitnose Point & 3,42 & 0.56 & 0.642 & \\
\hline \multicolumn{5}{|l|}{ Gonad index } \\
\hline Black Rock & 4,48 & 10.83 & $<0.001$ & $04016024080^{*}$ \\
\hline Duncan's Cove & 4,64 & 51.37 & $<0.001$ & $\overline{40080160240}$ \\
\hline Gill Cove & 4,45 & 15.11 & $<0.001$ & $\overline{0 \underline{40}} 80 \overline{160240}$ \\
\hline Splitnose Point & 4,61 & 22.98 & $<0.001$ & $\overline{04080160240}$ \\
\hline \multicolumn{5}{|c|}{ Kelp in gut contents (\%) } \\
\hline Black Rock & 4,39 & 10.67 & $<0.001$ & $160 \underline{40 \underline{0} 80240}$ \\
\hline Duncan's Cove & 4,61 & 27.68 & $<0.001$ & $040 \overline{80} 160240 *$ \\
\hline Gill Cove & 4,43 & 9.08 & $<0.001$ & $\overline{040160 \overline{80240}}$ \\
\hline Splitnose Point & 4,56 & 0.86 & 0.492 & \\
\hline \multicolumn{5}{|c|}{ Coralline algae in gut contents $(\%)$} \\
\hline Black Rock & 4,39 & 13.08 & $<0.001$ & $800 \underline{240} \underline{40} 160^{*}$ \\
\hline Duncan's Cove & 4,61 & 9.33 & $<0.001$ & $160 \underline{24080040}$ \\
\hline Gill Cove & 4,43 & 2.37 & 0.068 & \\
\hline Splitnose Point & 4,56 & 13.64 & $<0.001$ & 24016080400 \\
\hline \multicolumn{5}{|l|}{ Muscle $\delta^{13} \mathrm{C}$} \\
\hline Black Rock & 4,22 & 1.24 & 0.325 & \\
\hline Duncan's Cove & 4,26 & 8.13 & $<0.001$ & 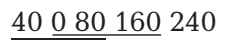 \\
\hline Gill Cove & 4,18 & 2.51 & 0.078 & \\
\hline Splitnose Point & 4,27 & 9.98 & $<0.001$ & $0 \underline{4080160240}$ \\
\hline \multicolumn{5}{|l|}{ Muscle $\delta^{15} \mathbf{N}$} \\
\hline Black Rock & 4,22 & 5.63 & 0.003 & $80240160 \underline{040}$ \\
\hline Duncan's Cove & 4,26 & 22.79 & $<0.001$ & 24016080400 \\
\hline Gill Cove & 4,18 & 9.35 & $<0.001$ & $\overline{240 \underline{160} 80400}$ \\
\hline Splitnose Point & 4,27 & 9.98 & $<0.001$ & $\overline{240160} \overline{80400}$ \\
\hline \multicolumn{5}{|l|}{ FA composition } \\
\hline Black Rock & 2,29 & 5.87 & 0.001 & 040160 \\
\hline Duncan's Cove & 4,49 & 2.29 & 0.011 & \\
\hline Gill Cove & 3,42 & 2.60 & 0.003 & 01604080 \\
\hline Splitnose Point & 3,42 & 1.76 & 0.039 & \\
\hline
\end{tabular}

FA composition of sea urchin gonads did not change with distance from the kelp bed, indicating that diets of sea urchins at all distances consisted of similar food items. Marker FA for kelp, identified in sea urchins fed single diets in the laboratory (Kelly et al. 2009), showed no spatial pattern with distance from the kelp bed in our study. FA markers may be more useful for identifying the presence of a unique food item in sea urchins (Cook et al. 2000, Castell et al. 2004, Kelly et al. 2009) than distinguishing among mixed diets with slightly different proportions of the same food items. Modification or selective retention of dietary FAs by sea urchins can obscure dietary information (Kelly et al. 2008, Kelly \& Scheibling in press) and may have masked spatial patterns in our study. Reduced lipid deposition in areas or during times of low food availability also could have biased our results. If sea urchins distant from the kelp bed only deposited lipid when food was abundant (i.e. drift kelp was available), their FA composition would be similar to that of sea urchins nearer to the kelp bed that more consistently deposit lipid of similar composition. FA signatures can be highly variable among individuals because they reflect metabolic processes that vary with age, food availability or reproductive status, while SI signatures tend to be less variable among individuals because they reflect environmental factors (Guest et al. 2010).

Kelp was present in the gut contents of $89 \%$ of the green sea urchins in our study. Similarly, BrittonSimmons et al. (2009) found kelp material in $97 \%$ of red sea urchins Strongylocentrotus franciscanus in deep barrens (23 m depth) adjacent to kelp beds off the Pacific coast in Washington, USA. Most specimens of $S$. franciscanus had only algal material in the gut contents (Britton-Simmons et al. 2009), whereas in our study we observed variable amounts of coralline algae, sediment, and bryozoa in sea urchins that were similar to the gut contents of sea urchins in shallow barrens (Meidel \& Scheibling 1998). This suggests that $S$. franciscanus in the Washington sites may receive sufficient drift algae to rely exclusively on this trophic subsidy, while $S$. droebachiensis at our sites receive less drift algae and therefore consume other foods.

We observed a decrease in the mean GI and test diameter of green sea urchins with increasing distance from the kelp bed. Gonad development and somatic growth are directly related to the quantity and quality of available food (Meidel \& Scheibling 1999), indicating that the nutritional condition of sea urchins decreased with distance from the kelp bed. Sea urchins 160 and $240 \mathrm{~m}$ from the kelp beds at Gill 
Table 3. Strongylocentrotus droebachiensis. Average contribution (percent \pm SE) of food items to gut contents at varying distances from the kelp bed at each site

\begin{tabular}{|c|c|c|c|c|c|c|c|c|c|c|}
\hline $\cos ^{8}$ & $\underset{y}{\underbrace{2}}$ & 还 & $0^{0^{\sigma^{\circ}}}$ & $v^{e^{b^{d^{2}}}}$ & 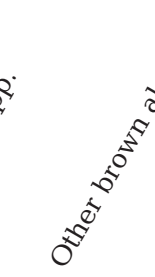 & 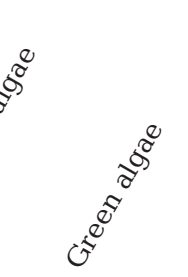 & $\overbrace{}^{\sigma^{2}}$ & 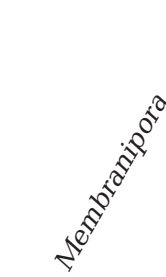 & 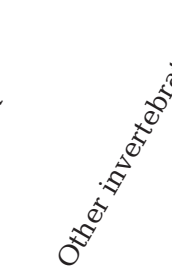 & 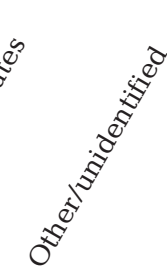 \\
\hline \multicolumn{11}{|c|}{ Black Rock } \\
\hline 0 & 7 & $31.8 \pm 7.36$ & $20.58 \pm 4.96$ & $5.26 \pm 4.71$ & $0.39 \pm 4.27$ & $4.47 \pm 1.59$ & $12.20 \pm 1.56$ & $0.59 \pm 0.25$ & $12.55 \pm 1.78$ & $12.15 \pm 0.59$ \\
\hline 40 & 8 & $51.5 \pm 3.86$ & $9.04 \pm 5.53$ & $0.00 \pm 0.53$ & $0.00 \pm 4.03$ & $5.53 \pm 2.45$ & $20.12 \pm 6.68$ & $4.46 \pm 0.00$ & $8.43 \pm 0.00$ & $0.97 \pm 3.53$ \\
\hline 80 & 11 & $16.5 \pm 4.51$ & $36.51 \pm 4.76$ & $1.98 \pm 2.26$ & $1.46 \pm 3.52$ & $0.58 \pm 0.39$ & $21.02 \pm 5.26$ & $0.34 \pm 1.14$ & $14.91 \pm 0.96$ & $6.74 \pm 0.34$ \\
\hline 160 & 10 & $64.4 \pm 5.37$ & $1.97 \pm 0.56$ & $0.37 \pm 2.86$ & $0.00 \pm 1.39$ & $1.17 \pm 0.55$ & $18.91 \pm 3.90$ & $2.71 \pm 0.00$ & $5.79 \pm 0.37$ & $4.65 \pm 1.70$ \\
\hline 240 & 8 & $30.0 \pm 7.92$ & $25.12 \pm 6.00$ & $0.00 \pm 3.85$ & $0.00 \pm 4.17$ & $2.31 \pm 1.41$ & $23.61 \pm 4.14$ & $0.59 \pm 0.00$ & $10.64 \pm 0.00$ & $7.74 \pm 0.42$ \\
\hline \multicolumn{11}{|c|}{ Duncan's Cove } \\
\hline 0 & 10 & $56.1 \pm 7.84$ & $7.61 \pm 4.03$ & $8.06 \pm 0.98$ & $0.29 \pm 1.64$ & $8.61 \pm 3.60$ & $11.97 \pm 2.69$ & $0.13 \pm 0.29$ & $5.35 \pm 2.67$ & $1.89 \pm 0.13$ \\
\hline 40 & 4 & $60.3 \pm 4.45$ & $0.37 \pm 0.37$ & $0.00 \pm 6.81$ & $0.00 \pm 3.13$ & $0.37 \pm 0.37$ & $5.58 \pm 3.93$ & $0.00 \pm 0.00$ & $22.01 \pm 0.00$ & $11.41 \pm 0.00$ \\
\hline 80 & 10 & $42.9 \pm 5.17$ & $10.05 \pm 3.89$ & $7.62 \pm 1.13$ & $0.43 \pm 3.17$ & $0.37 \pm 0.37$ & $24.46 \pm 6.48$ & $0.31 \pm 0.32$ & $10.41 \pm 2.32$ & $3.40 \pm 0.21$ \\
\hline 160 & 14 & $9.6 \pm 3.26$ & $34.02 \pm 6.58$ & $12.27 \pm 5.11$ & $0.44 \pm 5.22$ & $0.33 \pm 0.24$ & $16.30 \pm 3.33$ & $0.00 \pm 0.31$ & $13.37 \pm 3.22$ & $13.67 \pm 0.00$ \\
\hline 240 & 28 & $11.8 \pm 1.80$ & $26.47 \pm 2.98$ & $8.15 \pm 2.34$ & $1.25 \pm 3.88$ & $2.20 \pm 0.87$ & $13.24 \pm 2.16$ & $0.04 \pm 0.43$ & $22.56 \pm 1.30$ & $14.27 \pm 0.04$ \\
\hline \multicolumn{11}{|c|}{ Gill Cove } \\
\hline 0 & 9 & $56.2 \pm 8.83$ & $16.51 \pm 8.82$ & $6.21 \pm 0.94$ & $0.45 \pm 1.72$ & $5.23 \pm 2.92$ & $7.65 \pm 2.37$ & $2.38 \pm 0.33$ & $3.32 \pm 3.61$ & $2.07 \pm 2.38$ \\
\hline 40 & 11 & $44.5 \pm 7.60$ & $13.76 \pm 4.77$ & $2.60 \pm 2.67$ & $0.11 \pm 1.84$ & $2.73 \pm 0.95$ & $24.46 \pm 4.47$ & $0.00 \pm 0.11$ & $6.44 \pm 1.64$ & $5.37 \pm 0.00$ \\
\hline 80 & 10 & $21.1 \pm 5.42$ & $21.08 \pm 3.45$ & $2.43 \pm 3.44$ & $1.67 \pm 3.80$ & $1.40 \pm 0.50$ & $29.39 \pm 8.75$ & $0.00 \pm 0.68$ & $12.81 \pm 1.54$ & $10.08 \pm 0.00$ \\
\hline 160 & 9 & $38.7 \pm 9.72$ & $24.26 \pm 6.03$ & $3.54 \pm 4.34$ & $0.14 \pm 7.01$ & $1.56 \pm 0.64$ & $12.30 \pm 6.23$ & $0.14 \pm 0.14$ & $11.16 \pm 1.96$ & $8.17 \pm 0.14$ \\
\hline 240 & 9 & $5.0 \pm 3.26$ & $37.84 \pm 7.63$ & $2.69 \pm 1.39$ & $0.18 \pm 9.88$ & $0.00 \pm 0.00$ & $2.42 \pm 0.95$ & $0.00 \pm 0.18$ & $49.42 \pm 1.27$ & $2.42 \pm 0.00$ \\
\hline \multicolumn{11}{|c|}{ Splitnose Point } \\
\hline 0 & 6 & $31.1 \pm 10.96$ & $5.43 \pm 2.08$ & $2.84 \pm 2.13$ & $0.00 \pm 4.29$ & $23.68 \pm 15.73$ & $27.46 \pm 10.19$ & $0.00 \pm 0.00$ & $7.38 \pm 2.84$ & $2.13 \pm 0.00$ \\
\hline 40 & 9 & $15.1 \pm 5.17$ & $11.99 \pm 2.89$ & $25.70 \pm 1.90$ & $0.14 \pm 2.31$ & $2.98 \pm 1.15$ & $28.09 \pm 6.45$ & $0.14 \pm 0.14$ & $8.97 \pm 3.97$ & $6.87 \pm 0.14$ \\
\hline 80 & 26 & $19.3 \pm 3.75$ & $18.15 \pm 1.91$ & $20.80 \pm 0.98$ & $0.47 \pm 2.18$ & $1.80 \pm 0.71$ & $26.32 \pm 3.34$ & $0.08 \pm 0.31$ & $10.20 \pm 2.85$ & $2.92 \pm 0.08$ \\
\hline 160 & 10 & $17.9 \pm 6.30$ & $37.06 \pm 7.39$ & $8.70 \pm 2.47$ & $1.25 \pm 2.94$ & $0.68 \pm 0.51$ & $13.58 \pm 4.64$ & $0.00 \pm 1.00$ & $14.43 \pm 1.75$ & $6.42 \pm 0.00$ \\
\hline 240 & 9 & $10.1 \pm 3.03$ & $46.37 \pm 6.19$ & $11.45 \pm 2.55$ & $0.00 \pm 2.02$ & $0.86 \pm 0.67$ & $16.50 \pm 4.84$ & $0.00 \pm 0.00$ & $9.75 \pm 3.43$ & $4.95 \pm 0.00$ \\
\hline
\end{tabular}

Table 4. Stable carbon $\left(\delta^{13} \mathrm{C}\right)$ and nitrogen $\left(\delta^{15} \mathrm{~N}\right)$ signatures (mean $\pm \mathrm{SE}$ ) of macroalgae

\begin{tabular}{|llccc|}
\hline Algal species & Site & $\mathrm{n}$ & $\delta^{13} \mathrm{C}(\%)$ & $\delta^{15} \mathrm{~N}(\%)$ \\
\hline Phaeophyta & & & & \\
Saccharina latissima & Black Rock & 3 & $-18.66 \pm 0.89$ & $4.03 \pm 1.00$ \\
& Duncan's Cove & 2 & $-17.36 \pm 0.18$ & $7.29 \pm 0.35$ \\
& Gill Cove & 3 & $-17.67 \pm 1.26$ & $6.14 \pm 1.52$ \\
& Splitnose Point & 3 & $-17.11 \pm 0.88$ & $6.71 \pm 0.42$ \\
Laminaria digitata & Black Rock & 2 & $-17.71 \pm 1.21$ & $4.59 \pm 0.79$ \\
& Duncan's Cove & 2 & $-14.96 \pm 0.97$ & $6.68 \pm 0.13$ \\
& Gill Cove & 1 & -17.01 & 4.92 \\
Agarum cribrosum & Splitnose Point & 2 & $-17.62 \pm 1.51$ & $5.02 \pm 1.81$ \\
Alaria esculenta & Duncan's Cove & 3 & $-23.57 \pm 0.68$ & $6.84 \pm 0.45$ \\
Desmarestia aculeata & Gill Cove & 3 & $-22.63 \pm 0.90$ & $4.88 \pm 0.30$ \\
Desmarestia viridis & Duncan's Cove & 3 & $-20.30 \pm 0.66$ & $5.88 \pm 0.57$ \\
Rhodophyta & Splitnose Point & 3 & $-32.99 \pm 0.12$ & $6.47 \pm 0.10$ \\
Bonnemaisonia hamifera Point & 3 & $-33.01 \pm 0.04$ & $6.10 \pm 0.04$ \\
Palmaria palmata & Splitnose Point & 3 & $-32.69 \pm 0.28$ & $5.50 \pm 0.22$ \\
& Gill Cove & 3 & $-33.86 \pm 0.39$ & $5.79 \pm 0.09$ \\
\hline
\end{tabular}

Cove and Duncan's Cove, and $240 \mathrm{~m}$ from the kelp bed at Splitnose Point, all had a mean GI of $<1$. Sea urchins raised on a diet of coralline algae in the laboratory generally do not develop gonads (Meidel \& Scheibling 1999). Therefore, the development of even small gonads in sea urchins at 160 to $240 \mathrm{~m}$ from the kelp bed suggests at least occasional access to an additional food source. The highest mean GI value, 22.4 at $40 \mathrm{~m}$ from the kelp bed at Duncan's Cove, was comparable with the maximum GI recorded for sea urchins in kelp beds (Meidel \& Scheibling 1998). The large accumulation of drift kelp present $40 \mathrm{~m}$ from the kelp bed at Duncan's Cove provided sea urchins with an abundant food source, which probably enabled them to develop larger 


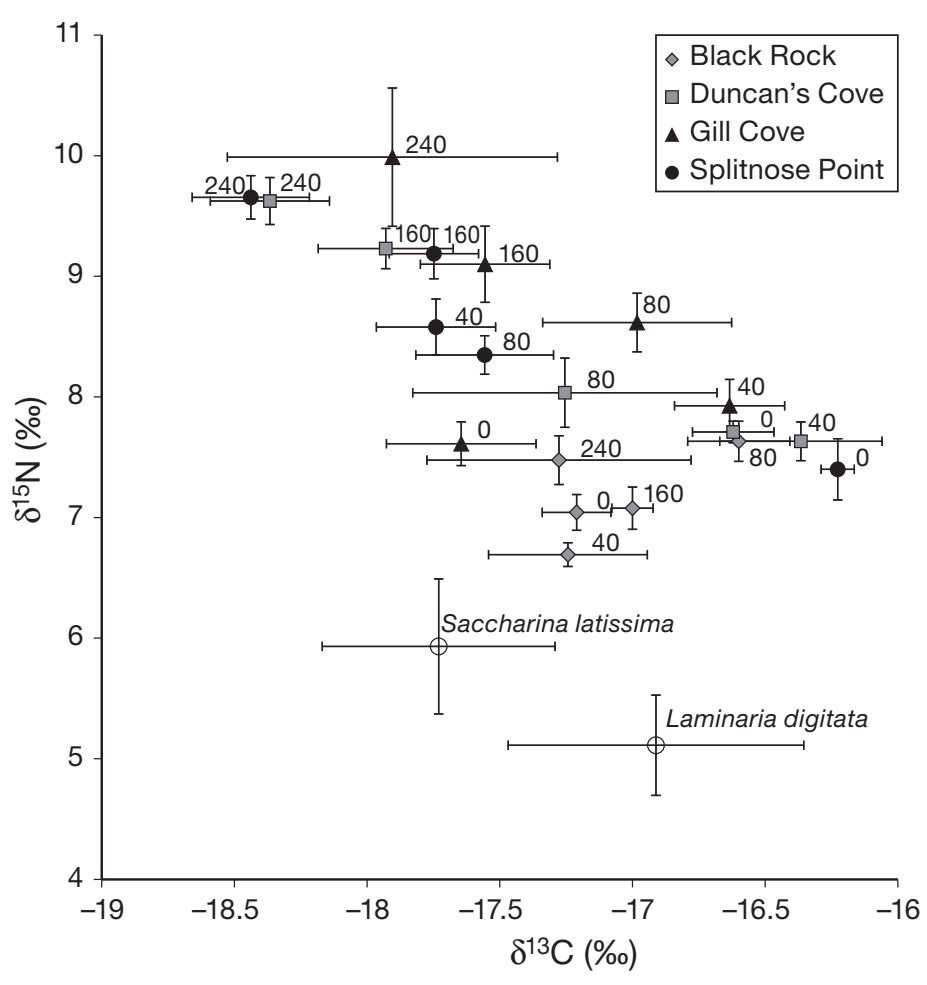

Fig. 4. Stable carbon $\left(\delta^{13} C\right)$ and nitrogen $\left(\delta^{15} N\right)$ values for green sea urchins Strongylocentrotus droebachiensis along transects offshore from kelp beds and for the 2 dominant kelp species, Saccharina latissima and Laminaria digitata. Numbers next to symbols indicate distance from kelp bed (m)

gonads. Degrading kelp has a lower C:N ratio than does fresh kelp (Norderhaug et al. 2003, Krumhansl \& Scheibling in press), and the higher nutritional quality of this food source also may have contributed to the high GI of sea urchins at this location. Given that the patterns we observed with distance from sources of kelp occurred at sites with different depth profiles, depth was probably less important than distance from kelp in determining drift kelp availability to sea urchins in the barrens.

The results of this study indicate that the influence of drift kelp extends at least $240 \mathrm{~m}$ from the kelp bed at our study sites. Recent video surveys at nearby sites have documented patches of drift kelp, often with clusters of sea urchins, up to $500 \mathrm{~m}$ offshore at depths of 30 to 85 m (K. Filbee-Dexter \& R. E. Scheibling unpubl. data), and individual kelp fronds have been observed, also with sea urchins, at depths of up to $3000 \mathrm{~m}$ on the continental slope off Nova Scotia (A. Metaxas pers. comm.). Other studies have found that drift kelp provides a substantial trophic subsidy to habitats kilometers away from kelp beds (Kirkman \&
Kendrick 1997, Vanderklift \& Kendrick 2005, Vanderklift \& Wernberg 2008). However, our results indicate that it is unlikely that drift kelp provides a consistent trophic subsidy to distant habitats. The spatial extent of this subsidy may depend on bottom topography, as negatively buoyant drift kelp is transported along the sea floor by wave-driven currents and deposited in depressions (Vetter \& Dayton 1999). Large quantities of detrital material probably are transported greater distances in winter storms (K. Filbee-Dexter \& R. E. Scheibling unpubl. data). Our results suggest that drift kelp accumulation is greatest in depositional areas with a relatively flat, sandy bottom. Outside of such depressions, it is likely that drift kelp becomes an increasingly patchy resource as distance increases from the kelp bed.

If sea urchin diets were uniform over time, all methods used in this study should have produced similar spatial patterns with respect to the contribution of drift kelp. The discrepancy among methods is probably due to differences in the temporal scale over which dietary information is integrated. FA analysis of gonad tissue and SI signatures of muscle tissue reflect diet in the longer term (months to years) (Meidel \& Scheibling 1998, Tomas et al. 2006), whereas gut contents represent diet on the scale of days to weeks (Sauchyn \& Scheibling 2009). Our results indicate that in the longer term, green sea urchins rely on drift kelp as a dietary subsidy, while gut contents indicate that this subsidy is increasingly patchy as distance increases from the source. Given the potential for SI and FA analysis to capture longerterm patterns, a combination of approaches that includes SI or FA and one or more other methods that captures shorter-term variability is likely to provide the most robust results in trophic studies of sea urchins in rocky subtidal ecosystems. Our results have also highlighted a limitation of FA analysis in this system and suggest that, among benthic food webs, the technique is better suited to distinguishing among animals of different functional groups. Other recent studies have used a combination of SIs and FAs to investigate the diets of many species of benthic organisms at various trophic levels (Alfaro et al. 2006, Richoux \& Froneman 2007, 2008). In these cases, FA data provided additional resolution for distinguishing diets of animals where primary producers overlapped in their $\delta^{13} \mathrm{C}$ signatures (Alfaro et al. 2006, Richoux \& Froneman 2007, 2008). FA analysis may be better suited to studies in which consumer diets vary widely, rather than in studies such as ours in which consumer diets vary only in the relative contribution of the a suite of food sources. 
Acknowledgements. We thank J. Lindley, D. Gray, D. Lyons, M. Saunders, A. Pinder, A. McCurdy and K. Filbee-Dexter for their assistance in the field, and S. Al-Shaghay, J. LeClerc and C. Stortini for laboratory support. We also thank S. Iverson and S. Budge for helpful discussions of this work, and 3 anonymous reviewers for their helpful comments on an earlier version of this manuscript. This research was funded by a Discovery Grant and a Strategic Networks Grant (Canadian Healthy Oceans Network) to R.E.S. from the Natural Sciences and Engineering Research Council (NSERC) of Canada, and a Research Tools and Instruments Grant to S. J. Iverson and R.E.S. from NSERC. J.R.K. was supported by a Killam Predoctoral Scholarship and a NSERC Canada Graduate Scholarship. K.A.K. was supported by a Dalhousie University Scholarship.

\section{LITERATURE CITED}

Alfaro AC, Thomas F, Sergent L, Duxbury M (2006) Identification of trophic interactions within an estuarine food web (northern New Zealand) using fatty acid biomarkers and stable isotopes. Estuar Coast Shelf Sci 70:271-286

Anderson MJ (2001) A new method for non-parametric multivariate analysis of variance. Austral Ecol 26:32-46

Anderson MJ (2004) PERMDISP: a FORTRAN computer program for permutational analysis of multivariate dispersions (for any two-factor ANOVA design) using permutation tests. Department of Statistics, University of Auckland

> Boolootian RA, Lasker R (1964) Digestion of brown algae and the distribution of nutrients in the purple sea urchin Strongylocentrotus purpuratus. Comp Biochem Physiol 11:273-289

Brady SM, Scheibling RE (2005) Repopulation of the shallow subtidal zone by green sea urchins (Strongylocentrotus droebachiensis) following mass mortality in Nova Scotia, Canada. J Mar Biol Assoc UK 85:1511-1517

Brady SM, Scheibling RE (2006) Changes in growth and reproduction of green sea urchins, Strongylocentrotus droebachiensis (Müller), during repopulation of the shallow subtidal zone after mass mortality. J Exp Mar Biol Ecol 335:277-291

Britton-Simmons KH, Gerard F, Okamoto D (2009) Spatial subsidy in the subtidal zone: utilization of drift algae by a deep subtidal sea urchin. Aquat Biol 5:233-243

Budge SM, Iverson SJ, Koopman HN (2006) Studying trophic ecology in marine ecosystems using fatty acids: a primer on analysis and interpretation. Mar Mamm Sci 22: 759-801

> Bustamante RH, Branch GM (1996) The dependence of intertidal consumers on kelp-derived organic matter on the west coast of South Africa. J Exp Mar Biol Ecol 196: $1-28$

> Bustamante RH, Branch GM, Eekhout S (1995) Maintenance of an exceptional intertidal grazer biomass in South Africa: subsidy by subtidal kelps. Ecology 76:2314-2329

> Castell JD, Kennedy EJ, Robinson SMC, Parsons GJ, Blair TJ, Gonzalez-Duran E (2004) Effect of dietary lipids on fatty acid composition and metabolism in juvenile green sea urchins (Strongylocentrotus droebachiensis). Aquaculture 242:417-435

Cebrian J (1999) Patterns in the fate of production in plant communities. Am Nat 154:449-468

Chapman ARO (1981) Stability of sea urchin dominated bar- ren grounds following destructive grazing of kelp in St. Margaret's Bay, Eastern Canada. Mar Biol 62:307-311

Clarke KR, Gorley RN (2006) PRIMER v6: user manual/tutorial. PRIMER-E, Plymouth

> Cook EJ, Bell MV, Black KD, Kelly MS (2000) Fatty acid compositions of gonadal material and diets of the sea urchin, Psammechinus milaris: trophic and nutritional implications. J Exp Mar Biol Ecol 255:261-274

> Crawley KR, Hyndes GA, Vanderklift MA, Revill AT, Nichols PD (2009) Allochthonous brown algae are the primary food source for consumers in a temperate, coastal environment. Mar Ecol Prog Ser 376:33-44

> Dalsgaard J, St. John M, Kattner G, Muller-Navarra D, Hagen W (2003) Fatty acid trophic markers in the pelagic marine environment. Adv Mar Biol 46:225-340

Foale S, Day R (1992) Recognizability of algae ingested by abalone. Mar Freshw Res 43:1331-1338

Folch J, Lees M, Sloane Stanley GH (1957) A simple method for the isolation and purification of total lipids from animal tissues. J Biol Chem 226:287-291

Graeve M, Kattner G, Hagen W (1994) Diet-induced changes in the fatty-acid composition of arctic herbivorous copepods: experimental evidence of trophic markers. J Exp Mar Biol Ecol 182:97-110

> Graeve M, Dauby P, Scailteur Y (2001) Combined lipid, fatty acid and digestive tract content analyses: a penetrating approach to estimate feeding modes of Antarctic amphipods. Polar Biol 24:853-862

Guest MA, Hirst AJ, Nichols PD, Frusher SD (2010) Multiscale spatial variation of stable isotope and fatty acid profiles amongst temperate reef species: implications for design and interpretation of trophic studies. Mar Ecol Prog Ser 410:25-41

Hanson CE, Hyndes GA, Wang SF (2010) Differentiation of benthic marine primary producers using stable isotopes and fatty acids: implications to food web studies. Aquat Bot 93:114-122

> Heck KL, Carruthers TJB, Duarte CM, Hughes AR, Kendrick G, Orth RJ, Williams SW (2008) Trophic transfers from seagrass meadows subsidize diverse marine and terrestrial consumers. Ecosystems 11:1198-1210

Himmelman JH (1986) Population biology of green sea urchins on rocky barrens. Mar Ecol Prog Ser 33:295-306

Himmelman JH, Steele DH (1971) Foods and predators of the green sea urchin Strongylocentrotus droebachiensis in Newfoundland waters. Mar Biol 9:315-322

Iverson SJ, Frost KJ, Lowry LF (1997) Fatty acid signatures reveal fine scale structure of foraging distribution of harbor seals and their prey in Prince William Sound, Alaska. Mar Ecol Prog Ser 151:255-271

Iverson SJ, Field C, Bowen WD, Blanchard W (2004) Quantitative fatty acid signature analysis: a new method of estimating predator diets. Ecol Monogr 74:211-235

Johnson CR, Mann KH (1982) Adaptations of Strongylocentrotus droebachiensis for survival on barren grounds in Nova Scotia. In: Lawrence JM (ed) Echinoderms: proceedings of the international conference, Tampa Bay. A. A. Balkema, Rotterdam, p 277-283

Kelly JR, Scheibling RE, Iverson SJ, Gagnon P (2008) Fatty acid profiles in the gonads of the sea urchin Strongylocentrotus droebachiensis on natural algal diets. Mar Ecol Prog Ser 373:1-9

Kelly JR, Scheibling RE, Iverson SJ (2009) Fatty acids tracers for native and invasive macroalgae in an experimental food web. Mar Ecol Prog Ser 391:53-63 
Kelly JR, Scheibling RE (2012) Fatty acids as dietary tracers in benthic food webs. Mar Ecol Prog Ser 446:1-22

Kharlamenko VI, Kiyashko SI, Imbs AB, Vyshkvartzev DI (2001) Identification of food sources of invertebrates from the seagrass Zostera marina community using carbon and sulfur stable isotope ratio and fatty acid analyses. Mar Ecol Prog Ser 220:103-117

Kirkman H, Kendrick GA (1997) Ecological significance and commercial harvesting of drifting and beach-cast macroalgae and seagrasses in Australia: a review. J Appl Phycol 9:311-326

Krumhansl KA, Scheibling RE (2011) Detrital production in Nova Scotian kelp beds: patterns and processes. Mar Ecol Prog Ser 421:67-82

Krumhansl KA, Scheibling RE (in press) Detrital subsidy from subtidal kelp beds is altered by the invasive green alga Codium fragile ssp. fragile. Mar Ecol Prog Ser

Lauzon-Guay JS, Scheibling RE (2007) Behaviour of sea urchin Strongylocentrotus droebachiensis grazing fronts: food-mediated aggregation and density-dependent facilitation. Mar Ecol Prog Ser 329:191-204

> Lyons DA, Scheibling RE (2008) Context-dependant survival of the invasive seaweed Codium fragile ssp. tomentosoides in kelp beds and urchin barren habitats off Nova Scotia. Aquat Biol 2:17-27

McDevit DC, Saunders GW (2010) A DNA barcode examination of the Laminariaceae (Phaeophyceae) in Canada reveals novel biogeographical and evolutionary insights. Phycologia 49:235-248

Meidel SK, Scheibling RE (1998) Annual reproductive cycle of the green sea urchin, Strongylocentrotus droebachiensis, in differing habitats in Nova Scotia, Canada. Mar Biol 131:461-478

Meidel SK, Scheibling RE (1999) Effects of food type and ration on reproductive maturation and growth of the sea urchin Strongylocentrotus droebachiensis. Mar Biol 134: 155-166

Molis M, Wessels H, Hagen W, Karsten U, Wiencke C (2009) Do sulphuric acid and the brown alga Desmarestia viridis support community structure in Arctic kelp patches by altering grazing impact, distribution patterns, and behaviour of sea urchins? Polar Biol 32:71-82

> Norderhaug KM, Fredriksen S, Nygaard K (2003) Trophic importance of Laminaria hyperborea to kelp forest consumers and the importance of bacterial degradation to food quality. Mar Ecol Prog Ser 255:135-144

Peterson BJ (1999) Stable isotopes as tracers of organic mat- ter input and transfer in benthic food webs: a review. Acta Oecol 20:479-487

Peterson BJ, Fry B (1987) Stable isotopes in ecosystem studies. Annu Rev Ecol Syst 18:293-320

> Polis GA, Anderson WB, Holt RD (1997) Toward an integration of landscape and food web ecology: the dynamics of spatially subsidized food webs. Annu Rev Ecol Syst 28: 289-316

Richoux NB, Froneman PW (2007) Assessment of spatial variation in carbon utilization by benthic and pelagic invertebrates in a temperate South African estuary using stable isotope signatures. Estuar Coast Shelf Sci 71: 545-558

> Rodriguez SR (2003) Consumption of drift kelp by intertidal populations of the sea urchins Tetrapygus niger on the central Chilean coast: possible consequences at different ecological levels. Mar Ecol Prog Ser 251:141-151

Rogers-Bennett L, Bennett WA, Fastenau HC, Dewees CM (1995) Spatial variation in red sea urchin reproduction and morphology: implications for harvest refugia. Ecol Appl 5:1171-1180

Sauchyn LK, Scheibling RE (2009) Degradation of sea urchin feces in a rocky subtidal ecosystem: implications for nutrient cycling and energy flow. Aquat Biol 6:99-108

Scheibling RE, Hatcher BG (2007) Ecology of Strongylocentrotus droebachiensis. In: Lawrence JM (ed) Edible sea urchins: biology and ecology. Elsevier, Amsterdam, p 353-392

> Tomas F, Álvarez-Cascos D, Turon X, Romero J (2006) Differential element assimilation by sea urchins Paracentrotus lividus in seagrass beds: implications for trophic interactions. Mar Ecol Prog Ser 306:125-131

> Vanderklift MA, Kendrick GA (2005) Contrasting influence of sea urchins on attached and drift macroalgae. Mar Ecol Prog Ser 299:101-110

Vanderklift MA, Wernberg T (2008) Detached kelps from distant sources are a food subsidy for sea urchins. Oecologia 157:327-335

Vetter EW (1998) Population dynamics of a dense assemblage of marine detritivores. J Exp Mar Biol Ecol 226:131-161

- Vetter EW, Dayton PK (1999) Organic enrichment by macrophyte detritus, and abundance patterns of megafaunal populations in submarine canyons. Mar Ecol Prog Ser 186:137-148

> Wernberg T, Vanderklift MA, How J, Lavery PS (2006) Export of detached macroalgae from reefs to adjacent seagrass beds. Oecologia 147:692-701 


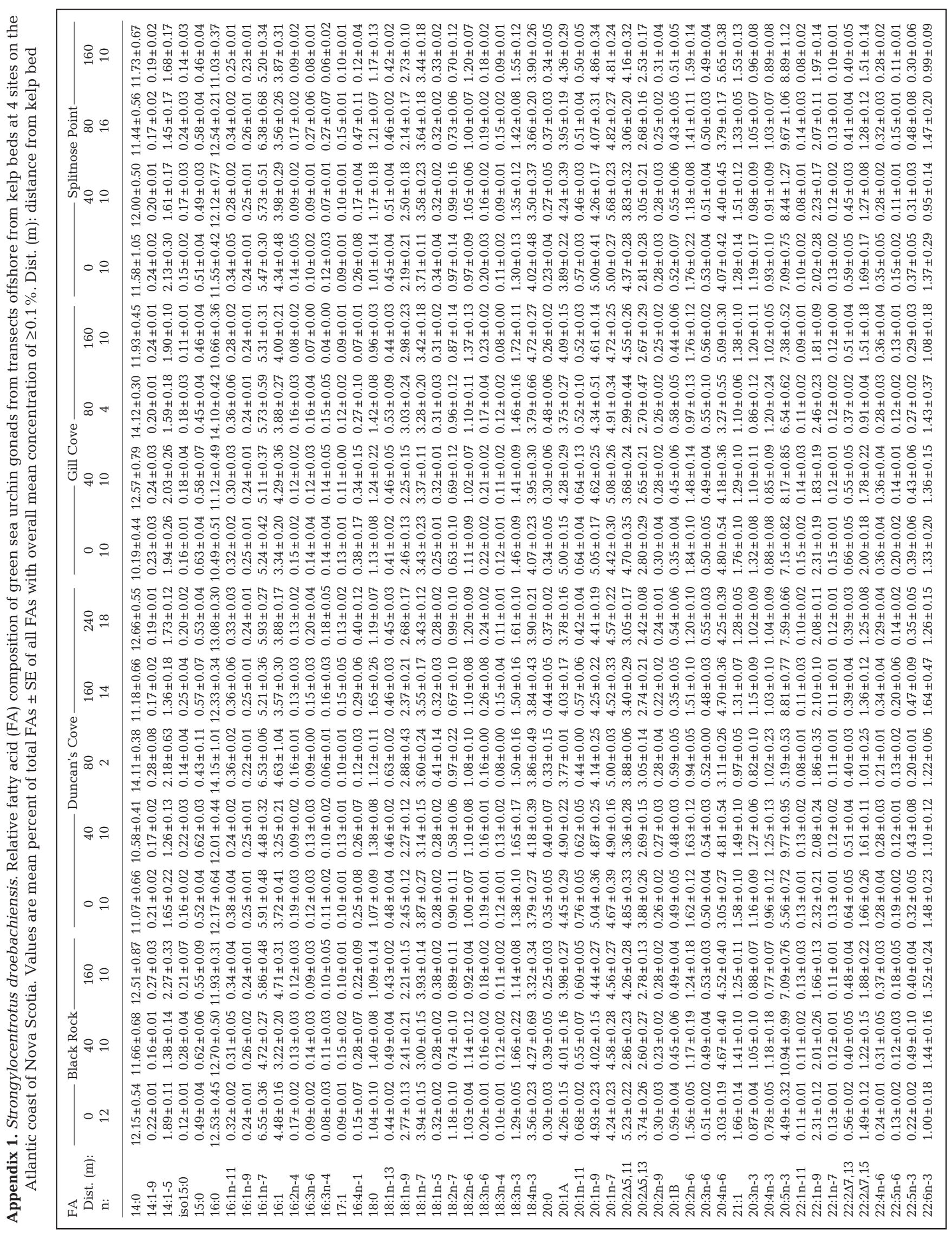

